\title{
Health literacy for people living with HIV/Aids: an integrative review
}

\author{
Letramento em saúde para pessoas com HIV/Aids: revisão integrativa \\ La alfabetización en salud para las personas que viven con el VIHISIDA: una revisión integradora
}

\section{Gilmara Holanda da Cunha', Marli Teresinha Gimeniz Galvão', Patrícia Neyva da Costa Pinheiro', Neiva Francenely Cunha Vieira'}

' Universidade Federal do Ceará, Department of Nursing. Fortaleza, Ceará, Brazil.

How to cite this article:

Cunha GH, Galvão MTG, Pinheiro PNC, Vieira NFC. Health literacy for people living with HIV/Aids: an integrative review. Rev Bras Enferm [Internet]. 2017;70(1):169-77. DOI: http://dx.doi.org/10.1590/0034-7167-2015-0052

Submission: 10-07-2015 Approval: 08-25-2016

\begin{abstract}
Objective: to analyze knowledge produced by research about health literacy for adult with HIV/Aids. Method: an integrative literature review, using six databases, was conducted between January and April of 2014. The descriptors aids and Health Literacy were used, in Portuguese, English and Spanish. A total of 130 articles were found and 14 were selected. Three categories were identified: educational technologies and health literacy for HIV/Aids; assessment of health literacy of patients with HIV/ Aids; and health literacy and adherence to antiretroviral therapy. Results: analysis of health literacy, socioeconomic status and educational level of people living with HIV/ Aids was essential for implementation of educational strategies that increased adherence to health guidance. Conclusion: this study showed the importance of health literacy for working with people living with HIV/Aids, especially considering individuals who did not possess the minimum necessary for survival, which makes it relevant and encourages further research on the topic.
\end{abstract}

Descriptors: HIV; Acquired Immunodeficiency Syndrome; Health Promotion; Nursing; Health Education.

\section{RESUMO}

Objetivo: analisar o conhecimento produzido por pesquisas sobre o letramento em saúde de pessoas com HIV/Aids. Método: uma revisão integrativa da literatura, utilizando seis bancos de dados, foi desenvolvida entre janeiro e abril de 2014. Os descritores Aids e Letramento em Saúde foram utilizados, em Português, Inglês e Espanhol. Um total de 130 artigos foram encontrados e 14 foram selecionados. Três categorias foram identificadas: tecnologias educacionais e letramento em saúde sobre HIV/Aids; avaliação do letramento em saúde de pacientes com HIV/Aids; e letramento em saúdee adesão ao tratamento antirretroviral. Resultados: a análise do letramento em saúde, status socioeconômico e nível educacional de pessoas com HIV/Aids foi essencial para a implementação de estratégias educacionais que aumentaram a adesão às orientações de saúde. Conclusão: este estudo mostrou a importância do letramento em saúde no trabalho com pessoas com HIV/Aids, principalmente considerando indivíduos que não possuem as condições mínimas necessárias para sobrevivência, o que promove e torna a pesquisa do tema relevante.

Descritores: HIV; Síndrome de Imunodeficiência Adquirida; Promoção da Saúde; Enfermagem; Educação em Saúde.

\section{RESUMEN}

Objetivo: analizar el conocimiento producido por la investigación sobre la salud de alfabetización para adultos con VIH/SIDA. Método: una revisión integradora de la literatura, con seis bases de datos, se llevó a cabo entre enero y abril de 2014. Los descriptores SIDA y Educación de la Salud se utilizaron, en portugués, inglés y español. Se encontró un total de 130 artículos y se seleccionaron 14. Se identificaron tres categorías: tecnologías de la educación y alfabetización de la salud para el VIH/SIDA; evaluación de conocimientos sobre la salud de los pacientes con VIH/SIDA; y conocimientos sobre la salud y la adherencia a la terapia antirretroviral. Resultados: análisis de los conocimientos sobre la salud, el estatus socioeconómico y nivel educativo de las personas que viven con el VIH / SIDA era esencial para la implementación de estrategias educativas que el aumento de la adherencia a la orientación de la salud. Conclusión: Este estudio demostró la importancia de la alfabetización en salud para 
trabajar con personas que viven con el VIH / SIDA, especialmente teniendo en cuenta a las personas que no poseen el mínimo necesario para la supervivencia, lo que hace que sea aún más relevante y alienta la investigación sobre el tema.

Descriptores: HIV; Síndrome de Inmunodeficiencia Adquirida; Promoción de la Salud; Enfermería; Educación en Salud.

\section{INTRODUCTION}

More than three decades after the recognition of acquired immunodeficiency syndrome (Aids), the pandemic of human immunodeficiency virus (HIV) infection has had changes in its characteristics ${ }^{(1-2)}$. There was a reduction in the number of new infections and deaths from HIV/Aids at the global level, due to the significant progress in preventing the spread of infection and an increase in the number of people who have access to antiretroviral therapy ${ }^{(3-4)}$. Therefore, health care becomes very important for these patients, since individuals require care to maintain quality of life ${ }^{(5)}$. Educational strategies are relevant in this process and can be developed in different contexts: HIV prevention, pre-test counseling, ambulatory care, among others. Educational practices must allow individuals the opportunity to know and recognize the achievement of dexterity to make decisions in the pursuit of quality of life.

However, studies show that the care provided to people living with HIV/Aids is complex because most have a low level of education. They often obtain guidance about health care, but some do not respond appropriately, and have various problems, such as: non-adherence to medication therapy, changes in sexual activity and diet, and inadequate hygiene habit ${ }^{(6-7)}$. The researchers wondered if health education was being provided at an appropriate level of understanding, when considering why these individuals did not adequately adhere to health guidelines. It appears that there is a need for health professionals to conduct educational activities on the basis of functional health literacy in order to be proactive, using multiple approaches for guidance, in order to inform and ensure that the patient is also able to understand ${ }^{(8)}$.

Literacy is a phenomenon resulting from the process of learning to read and write, that is, the condition that an individual acquires after having appropriated writing skills and social practices. Health literacy is the cognitive ability to understand, interpret and implement written or spoken information about health; such that, in practical terms, a person with a satisfactory level of health literacy would have better health status than an individual with a limited literacy level, who would therefore be less aware of the importance of preventive measures or treatment ${ }^{(9)}$. This dialogic relationship becomes possible when critical thinking and restlessness of the health professional do not interfere with the individual's ability to reflect. Thus, it is important to develop strategies for vulnerable populations and patients ${ }^{(10)}$.

Studies show that the use of educational strategies that take into account functional literacy in health are essential for patients to have appropriate follow-up health guidelines ${ }^{(7-10)}$. However, it must be considered that functional literacy in health does not always have a relation to education, because many patients with a high level of education do not follow the guidelines of the multidisciplinary health team adequately ${ }^{(7-8)}$. It is precisely this fact that raises discussions on functional literacy in health and requires further research regarding the topic, especially studies that consider different types of patients and diseases, since each situation has its singularities.

The significant impact of limited health literacy on health outcomes makes health literacy a crucial area for health professionals to fully understand ${ }^{(11)}$. Furthermore, HIV infection is one of the most serious public health problems worldwide, representing a multifaceted challenge, especially due to the absence of an effective treatment that leads to healing, in addition to the social and economic barriers that interfere in its prevention, grievances and adherence to the therapeutic regimen. Considering all these variables and the importance of health education, the aim of this study was to analyze the knowledge produced by research that focused on functional health literacy for adult patients with HIV/Aids. In evidencebased practice, one of the strategies used to build research questions is the PICO strategy, which is the acronym for Patient, Intervention, Comparison and Outcomes ${ }^{(12-14)}$. It was used to formulate the guiding question of this research: What studies investigated health literacy of patients with HIV/Aids? This study could be beneficial for health professionals, especially nurses who perform daily health education activities with patients.

\section{METHOD}

This was an integrative literature review, a method that gathered and systematically summarized the results of research about a particular topic, allowing the incorporation of evidence into clinical practice ${ }^{(12)}$. The present review was conducted in six steps: 1. Preparation of the guiding question; 2. Literature search; 3. Data collection; 4. Critical analysis of the included studies; 5 . Discussion of results; 6 . Presentation of the integrative review ${ }^{(13)}$.

The question guiding of this literature review sought to identify studies that investigated health literacy of patients with HIV/Aids. Articles were selected from six databases: Latin American and the Caribbean Health Sciences Literature (LILACS), Scientific Electronic Library Online (SciELO), Medical Literature Analysis and Retrieval System Online (MEDLINE),Cumulative Index to Nursing and Allied Health Literature (CINAHL), SCOPUS and COCHRANE.

The search for articles was conducted between January and April of 2014, using the descriptors or keywords extracted from the Health Sciences Descriptors (DeCS) database of the Virtual Health Library and from the Medical Subject Headings (MeSH) of the National Library of Medicine: Síndrome da Imunodeficiência 
Adquirida and Letramento Funcional em Saúde, Acquired Immunodeficiency Syndrome and Health Literacy, Síndrome de Inmunodeficiencia Adquirida and Letramiento Funcional en Salud, respectively, in Portuguese, English and Spanish.

Inclusion criteria were: full papers available electronically, in Portuguese, English and Spanish, without limitation of the publication year, and the theme involving health literacy and adults with HIV/Aids. Exclusion criteria consisted of letters to the editor, articles duplicated in different databases, and those that did not pertain to the guiding question of the study.

After obtaining all related material, the research articles were analyzed using an organized approach to examine the accuracy and features of each study, obtaining the following information: identification, methodological characteristics, intervention or proposed analysis, results, completion and levels of evidence. The classification of levels of evidence was as follows: I: The evidence came from a systematic review or meta-analysis of all relevant randomized controlled trials or was derived from clinical guidelines based on systematic reviews of randomized controlled trials; II: Evidence derived from at least one, welldelineated, randomized controlled trial; III: Evidence obtained from well-designed clinical trials without randomization; IV: Evidence from well-delineated cohort and case-control studies; V: Evidence originating from systematic reviews of descriptive and qualitative studies; VI: Evidence derived from a single descriptive or qualitative study; VII: Evidence from opinion of authorities and/or the report of expert committees ${ }^{(14)}$.

Figure 1 shows the distribution of the articles found and those selected according to the inclusion criteria. In the LILACS and SciELO databases, no articles that matched the study theme were found (Figure 1).

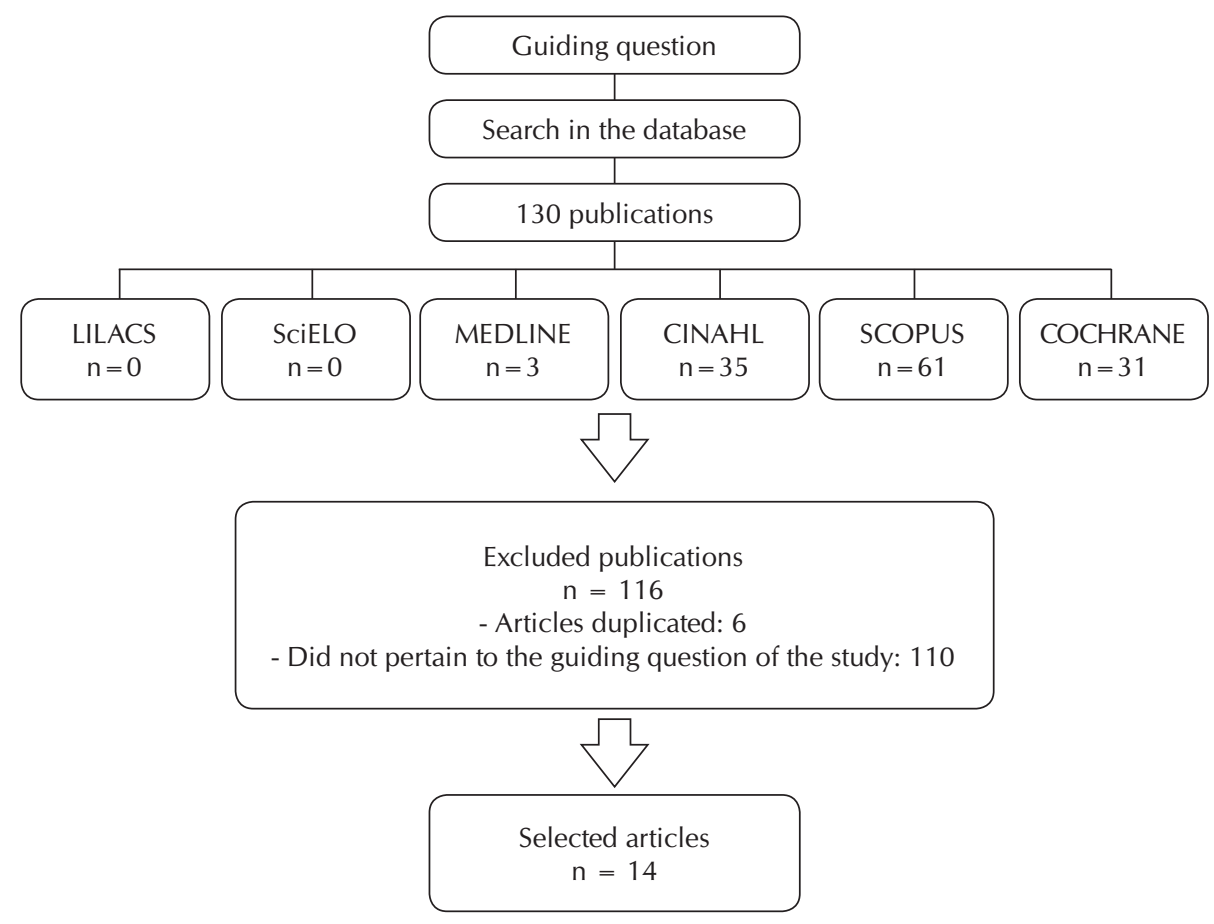

Figure 1 - Distribution of the articles found and selected
After reading the selected articles, studies were grouped into three categories: educational technologies and health literacy for patients with HIV/Aids; evaluation of health literacy of patients with HIV/Aids; health literacy and adherence to antiretroviral therapy.

Subsequently, the findings were discussed descriptively, based on scientific literature on the subject. Regarding the ethical aspects, the study was conducted respecting the writings of selected articles and copyright, and no modification was performed on the content found to favor any of the proposed studies by the authors.

\section{RESULTS}

The characterization of 14 articles showed that the year of publication ranged from 2003 to 2013, nine were published in the United States and five in the United Kingdom. Regarding their levels of evidence ${ }^{(14)}$, the following distribution was observed: one level II ${ }^{(15)}$ and thirteen level VI.

Four studies involved educational technology and health literacy for patients with HIV/Aids, five addressed assessment of health literacy of patients with HIV/Aids, and five involved health literacy and adherence to antiretroviral therapy.

Regarding the studies related to educational technologies that involved the health literacy of people living with HIV/ Aids, it was observed that in general, the four selected studies showed different technologies which had benefits for the health education of patients. The interventions occurred with individuals, groups and even via smartphoneas. The activities conducted in the studies involved prevention practices for HIV infection and reinfection, visual intervention via smartphone to improve adherence to antiretroviral treatment in people with HIV/Aids, counseling for adherence to HIV/Aids treatment, and educational programs to improve the knowledge and skills to follow the treatment regimen of HIV/Aids (Chart 1).

Of the five studies that assessed the health literacy of patients with HIV/Aids, patients had low health literacy in two studies. In one study there was a contradictory result, where individuals with higher literacy showed the worst results for the monitoring of health guidelines. While in the other two studies, the instruments used to measure the level of health literacy were not satisfactory for this purpose, requiring more targeted research and improved monitoring (Chart 2).

Adherence to antiretroviral drugs was also observed regarding the issue of health literacy. 
The studies concluded that low health literacy was directly related to poor adherence to antiretroviral therapy. Moreover, other factors such as lower educational and socioeconomic levels also negatively interfered in the conduct of the treatment of HIV/Aids. Therefore, the aforementioned articles emphasized the importance of educational strategies to observe and contemplate all the different variables related to the life conditions in these patients. Another point raised in the articles was the need to facilitate communication between health professionals and patients (Chart 3).

Chart 1 - Studies related to the development of educational technologies regarding health literacy for patients with HIV/Aids

\begin{tabular}{|c|c|c|c|c|}
\hline Title & Year & Purpose & Study design & Conclusion \\
\hline $\begin{array}{l}\text { Problem posing } \\
\text { and cultural } \\
\text { tailoring: } \\
\text { developing } \\
\text { an HIV/Aids } \\
\text { health literacy } \\
\text { toolkit with the } \\
\text { African American } \\
\text { community }^{(16)} \text {. }\end{array}$ & 2012 & $\begin{array}{l}\text { Development of an } \\
\text { educational tool based on } \\
\text { the educational philosophy } \\
\text { of Paulo Freire, using focus } \\
\text { groups and reading material, } \\
\text { involving health literacy for } \\
\text { prevention of infection and } \\
\text { reinfection with HIV in Africa. } \\
\text { Sample: } 24 \text { participants. }\end{array}$ & $\begin{array}{l}\text { Development of the HIV/Aids health } \\
\text { literacy toolkit occurred in two stages. } \\
\text { In stage 1, a nonprofit organization } \\
\text { and the research team established a } \\
\text { collaborative partnership to develop a } \\
\text { culturally tailored HIV/Aids HL toolkit. } \\
\text { In stage 2, African American community } \\
\text { members participated in focus } \\
\text { groups conducted as Freirian cultural } \\
\text { circles to further refine the HIV/Aids } \\
\text { health literacy toolkit. In both stages, } \\
\text { problem posing engaged participants' } \\
\text { knowledge, experiences, and concerns } \\
\text { to evaluate a working draft toolkit. }\end{array}$ & $\begin{array}{l}\text { The educational tool improved } \\
\text { access to health information } \\
\text { in an adapted manner to the } \\
\text { culture of individuals. }\end{array}$ \\
\hline $\begin{array}{l}\text { Designing } \\
\text { interventions } \\
\text { to overcome } \\
\text { poor numeracy } \\
\text { and improve } \\
\text { medication } \\
\text { adherence in } \\
\text { chronic illness, } \\
\text { including HIV/ } \\
\text { Aids }{ }^{(17)} \text {. }\end{array}$ & 2011 & $\begin{array}{l}\text { Description of visual } \\
\text { intervention using } \\
\text { smartphones to improve } \\
\text { medication adherence in } \\
\text { populations with chronic } \\
\text { diseases such as HIV/Aids. } \\
\text { Sample: } 12 \text { participants. }\end{array}$ & $\begin{array}{l}\text { Personalized graphical } \\
\text { representations of plasma medication } \\
\text { concentration and dynamic disease } \\
\text { state simulation were used to } \\
\text { overcome poor numeracy. These } \\
\text { methods incorporate efficient, } \\
\text { precise, and clear graphical data; } \\
\text { cartographical techniques focused on } \\
\text { judicious use of color intensities; and } \\
\text { animation that increases engagement } \\
\text { and accentuates information transfer. }\end{array}$ & $\begin{array}{l}\text { An educational tool can } \\
\text { improve adherence to therapy. } \\
\text { It was found that numeracy, an } \\
\text { element of health literacy, refers } \\
\text { to the ability to understand } \\
\text { related numerical information, } \\
\text { describing the degree to which } \\
\text { individuals can access, process, } \\
\text { interpret and act on health } \\
\text { information from graphical } \\
\text { and probabilistic mechanisms, } \\
\text { when threat to individual's } \\
\text { perception and response to } \\
\text { treatment is deficient, with low } \\
\text { levels of medication adherence. }\end{array}$ \\
\hline $\begin{array}{l}\text { Nurse-delivered } \\
\text { antiretroviral } \\
\text { treatment } \\
\text { adherence } \\
\text { intervention for } \\
\text { people with low } \\
\text { literacy skills and } \\
\text { living with HIV/ } \\
\text { Aids }^{(18)} \text {. }\end{array}$ & 2005 & $\begin{array}{l}\text { Pilot test of counseling } \\
\text { intervention for adherence } \\
\text { to HIV treatment guided } \\
\text { by theory of behavior } \\
\text { change, health and health } \\
\text { education for people with } \\
\text { low levels of health literary } \\
\text { and antiretroviral medication } \\
\text { adherence. Sample: } 30 \\
\text { participants. }\end{array}$ & $\begin{array}{l}\text { The authors undertook the } \\
\text { development and pilot testing of a brief } \\
\text { HIV treatment adherence improvement } \\
\text { counseling intervention for people } \\
\text { with low health literacy who were } \\
\text { taking antiretroviral medications. } \\
\text { Guided by a theory of health behavior } \\
\text { change, health education principles for } \\
\text { low literacy populations, and formative } \\
\text { research, the authors designed a two- } \\
\text { session plus one booster session nurse- } \\
\text { delivered HIV treatment adherence } \\
\text { intervention. }\end{array}$ & $\begin{array}{l}\text { Results of a pilot test with } 30 \\
\text { men and women with HIV and } \\
\text { low health literacy showed } \\
\text { that intervention increased } \\
\text { knowledge about HIV/Aids, } \\
\text { intention to improve and } \\
\text { self-efficacy for medication } \\
\text { adherence. Participants } \\
\text { exposed to intervention also } \\
\text { showed improvement in } \\
\text { medication adherence, and } \\
\text { reductions in the number of } \\
\text { tablets forgotten. }\end{array}$ \\
\hline $\begin{array}{l}\text { Program to } \\
\text { enhance health } \\
\text { literacy and } \\
\text { treatment } \\
\text { adherence in } \\
\text { low-income HIV- } \\
\text { infected Latino } \\
\text { men and women. } \\
\text { Aids Patient Care } \\
\text { and STDS }{ }^{(15)} \text {. }\end{array}$ & 2003 & $\begin{array}{l}\text { Evaluation of acceptance and } \\
\text { effectiveness of a program } \\
\text { to improve health literacy } \\
\text { in low-income Latino men } \\
\text { and women with HIV, } \\
\text { who received antiretroviral } \\
\text { therapy. It was a program of } \\
\text { instructional modular support } \\
\text { with follow-up of } 5 \text { weeks to } 6 \\
\text { months by a nurse. Objectives } \\
\text { of the program were to } \\
\text { improve knowledge and skills, } \\
\text { build confidence to follow the } \\
\text { treatment regimen, and teach } \\
\text { assertive communication. } \\
\text { Sample: } 81 \text { participants. }\end{array}$ & $\begin{array}{l}\text { Participants rated the program highly } \\
\text { on measures of satisfaction, providing } \\
\text { evidence of its acceptability. The } \\
\text { effectiveness of the program was } \\
\text { assessed in comparisons of the } \\
\text { intervention }(n=41) \text { and standard } \\
\text { care only }(n=40) \text { groups at baseline } \\
\text { and 6-week intervals. }\end{array}$ & $\begin{array}{l}\text { Program participants showed } \\
\text { significant improvement on } \\
\text { knowledge related to HIV/ } \\
\text { Aids, its treatment, and } \\
\text { understanding of the technical } \\
\text { terms related to HIV infection, } \\
\text { compared to participants in the } \\
\text { comparison group. }\end{array}$ \\
\hline
\end{tabular}


Chart 2 - Studies related to the analysis of health literacy of patients with HIV/Aids

\begin{tabular}{|c|c|c|c|c|}
\hline Title & Year & Purpose & Study design & Conclusion \\
\hline $\begin{array}{l}\text { Seeking information } \\
\text { about HIV/Aids: a } \\
\text { qualitative study of } \\
\text { health literacy among } \\
\text { people living with } \\
\text { HIV/Aids in a low } \\
\text { prevalence context }^{(19)} \text {. }\end{array}$ & 2011 & $\begin{array}{l}\text { Analysis of the level of } \\
\text { health literacy of a rural } \\
\text { population with HIV/Aids. } \\
\text { Sample: } 19 \text { participants }\end{array}$ & $\begin{array}{l}\text { In qualitative semi- } \\
\text { structured interviews, } \\
\text { participants' primary } \\
\text { sources of information, } \\
\text { types of information sought, } \\
\text { and barriers to accessing } \\
\text { information were explored. }\end{array}$ & $\begin{array}{l}\text { It was necessary to expand research } \\
\text { and specific interventions on } \\
\text { health literacy to address social and } \\
\text { structural barriers among those who } \\
\text { lived in areas of low HIV prevalence, } \\
\text { such as in rural areas, which had low } \\
\text { health literacy. }\end{array}$ \\
\hline $\begin{array}{l}\text { The relationship } \\
\text { between health literacy, } \\
\text { knowledge of health } \\
\text { status, and beliefs about } \\
\text { HIV/Aids transmission } \\
\text { among Ryan White } \\
\text { clients in Miami }{ }^{(20)} \text {. }\end{array}$ & 2012 & $\begin{array}{l}\text { Analysis of the level of } \\
\text { health literacy of patients } \\
\text { with HIV/Aids in Miami. } \\
\text { Sample: } 694 \text { participants. }\end{array}$ & $\begin{array}{l}\text { Convenience sampled, } \\
\text { quantitative analysis captured } \\
\text { with closed- and open-ended } \\
\text { interviews. }\end{array}$ & $\begin{array}{l}\text { A significant proportion of patients } \\
\text { with HIV/Aids had low levels of } \\
\text { health literacy, having difficulty } \\
\text { receiving health education, or reading } \\
\text { educational materials. }\end{array}$ \\
\hline $\begin{array}{l}\text { The association among } \\
\text { literacy, numeracy, } \\
\text { HIV knowledge and } \\
\text { health-seeking behavior: } \\
\text { a population-based } \\
\text { survey of women in } \\
\text { rural Mozambique }^{(21)} \text {. }\end{array}$ & 2012 & $\begin{array}{l}\text { Validation of a scale to } \\
\text { assess literacy, numeracy, } \\
\text { knowledge and behavior } \\
\text { regarding HIV, in a } \\
\text { population of women } \\
\text { in rural Mozambique. } \\
\text { Sample: } 3,557 \\
\text { participants. }\end{array}$ & $\begin{array}{l}\text { A validated measure of literacy } \\
\text { and numeracy, the Wide Range } \\
\text { Achievement Test, version } \\
3 \text { (WRAT-3), was translated } \\
\text { into Portuguese, adapted for } \\
\text { a Mozambican context, and } \\
\text { administered to a cross-section } \\
\text { of female heads-of-household. }\end{array}$ & $\begin{array}{l}\text { The subscales of literacy and } \\
\text { numeracy were valid and adapted } \\
\text { for use in rural Mozambican women. } \\
\text { Limited literacy and numeracy skills } \\
\text { were common and associated with } \\
\text { less knowledge about HIV. }\end{array}$ \\
\hline $\begin{array}{l}\text { Health literacy and } \\
\text { health outcomes in HIV } \\
\text { seropositive persons }{ }^{(7)} \text {. }\end{array}$ & 2007 & $\begin{array}{l}\text { Evaluation of the } \\
\text { influence of the personal } \\
\text { characteristics and health } \\
\text { literacy in relation to body } \\
\text { changes, depression and } \\
\text { intensity of symptoms } \\
\text { resulting from HIV infection. } \\
\text { Sample: } 489 \text { participants. }\end{array}$ & $\begin{array}{l}\text { Cross-sectional study. Health } \\
\text { literacy was measured with } \\
\text { the Rapid Estimate of Adult } \\
\text { Literacy in Medicine (REALM) } \\
\text { instrument. }\end{array}$ & $\begin{array}{l}\text { Despite the fact that health literacy was } \\
\text { associated with better health outcomes, } \\
\text { people with higher literacy reported } \\
\text { significantly worse health outcomes. } \\
\text { This unexpected relationship required } \\
\text { further exploration using longitudinal } \\
\text { studies and scales to more specifically } \\
\text { assess health literacy. }\end{array}$ \\
\hline $\begin{array}{l}\text { Do brief screening } \\
\text { questions or provider } \\
\text { perception accurately } \\
\text { identify persons with } \\
\text { low health literacy in } \\
\text { the HIV primary care } \\
\text { setting? }{ }^{(22)} \text {. }\end{array}$ & 2010 & $\begin{array}{l}\text { Determining the accuracy } \\
\text { of a screening instrument } \\
\text { with brief questions for } \\
\text { people with low health } \\
\text { literacy in the context } \\
\text { of HIV in primary care, } \\
\text { raising the hypothesis that } \\
\text { a brief screening to identify } \\
\text { low health literacy was } \\
\text { more accurate than the } \\
\text { perception of the provider } \\
\text { or self-reporting. Sample: } \\
147 \text { participants. }\end{array}$ & $\begin{array}{l}\text { The accuracy of provider } \\
\text { perception and previously } \\
\text { described brief screening } \\
\text { questions for identification } \\
\text { of low health literacy among } \\
\text { persons attending two } \\
\text { HIV specialty clinics were } \\
\text { examined. }\end{array}$ & $\begin{array}{l}\text { The brief screening tool had } \\
\text { insufficient information on the } \\
\text { likelihood of low health literacy, which } \\
\text { made the instrument insufficient for use } \\
\text { in screening in primary care for people } \\
\text { with HIV. In the absence of screening } \\
\text { tools for health literacy that are fast } \\
\text { and accurate, healthcare professionals } \\
\text { should consider interventions to } \\
\text { improve health communication with } \\
\text { patients. Simple interventions include } \\
\text { creating clinical materials written at a } \\
\text { reading level accessible to all patients, } \\
\text { the routine use of visuals, confirmation } \\
\text { of patient understanding when } \\
\text { discussing care, and avoiding the use } \\
\text { of technical terms. These interventions } \\
\text { could benefit all patients, especially } \\
\text { those with low health literacy. }\end{array}$ \\
\hline
\end{tabular}

Chart 3 - Studies related to the interference of health literacy on adherence to antiretroviral therapy in patients with HIV/Aids

\begin{tabular}{|c|c|c|c|c|}
\hline Title & Year & Purpose & Design & Conclusion \\
\hline $\begin{array}{l}\text { Stress and } \\
\text { poverty } \\
\text { predictors } \\
\text { of treatment } \\
\text { adherence } \\
\text { among people } \\
\text { with low-literacy } \\
\text { living with HIV/ } \\
\text { Aids }^{(23)} \text {. }\end{array}$ & 2010 & $\begin{array}{l}\text { Analysis of association between } \\
\text { social development, health, and } \\
\text { stressors related to poverty in } \\
\text { relation to antiretroviral therapy } \\
\text { adherence in a sample of } \\
\text { people with low literacy living } \\
\text { with HIV/Aids in southeastern } \\
\text { United States. Sample: } 188 \\
\text { participants. }\end{array}$ & $\begin{array}{l}\text { One hundred eighty-eight men and } \\
\text { women living with HIV/Aids who } \\
\text { demonstrated poor health literacy } \\
\text { completed measures of social and } \\
\text { health-related stress, indicators of } \\
\text { extreme poverty, as well as other factors } \\
\text { associated with non adherence. HIV } \\
\text { treatment adherence was monitored } \\
\text { prospectively, using unannounced pill } \\
\text { counts. }\end{array}$ & $\begin{array}{l}\text { The shortage of food, hunger, } \\
\text { depression, internalized stigma, drug } \\
\text { use and social stressors associated } \\
\text { with HIV contributed to non } \\
\text { adherence to antiretroviral therapy. } \\
\text { In socially disadvantaged people in } \\
\text { developing countries, poverty, food } \\
\text { insufficiency and hunger should be } \\
\text { directly addressed. }\end{array}$ \\
\hline
\end{tabular}


Chart 3 (concluded)

\begin{tabular}{|c|c|c|c|c|}
\hline Title & Year & Purpose & Design & Conclusion \\
\hline $\begin{array}{l}\text { Association } \\
\text { between health } \\
\text { literacy and } \\
\text { HIV treatment } \\
\text { adherence: } \\
\text { further evidence } \\
\text { from objectively } \\
\text { measured } \\
\text { medication } \\
\text { adherence }^{(24)} \text {. }\end{array}$ & 2008 & $\begin{array}{l}\text { Analysis of the association } \\
\text { between health literacy and } \\
\text { adherence to HIV treatment. } \\
\text { Sample: } 145 \text { participants. }\end{array}$ & $\begin{array}{l}\text { Men and women receiving } \\
\text { antiretroviral therapy completed a } \\
\text { test of health literacy and measures } \\
\text { of common adherence markers. } \\
\text { Medication adherence was monitored } \\
\text { by unannounced pill counts. }\end{array}$ & $\begin{array}{l}\text { Association between literacy } \\
\text { and adherence existed and was } \\
\text { confirmed using an objective } \\
\text { measure of medication adherence. }\end{array}$ \\
\hline $\begin{array}{l}\text { HIV treatment } \\
\text { adherence, } \\
\text { patient health } \\
\text { literacy, and } \\
\text { health care } \\
\text { provider-patient } \\
\text { communication: } \\
\text { results from } \\
\text { the } 2010 \text { Aids } \\
\text { treatment for } \\
\text { life international } \\
\text { survey }{ }^{(25)} \text {. }\end{array}$ & 2012 & $\begin{array}{l}\text { International survey aimed } \\
\text { to analyze patients from } \\
\text { different countries in relation } \\
\text { to the level of adherence to } \\
\text { antiretrovirals, health literacy } \\
\text { and communication with } \\
\text { health professionals. Sample: } \\
2,035 \text { participants. }\end{array}$ & $\begin{array}{l}\text { The Aids Treatment for Life } \\
\text { International Survey was a } \\
\text { multicountry cross-sectional study. A } \\
\text { 40-minute interview was conducted } \\
\text { using a standardized self-report } \\
\text { adherence questionnaire. }\end{array}$ & $\begin{array}{l}\text { Different levels of adherence } \\
\text { to antiretrovirals in different } \\
\text { geographic regions and low } \\
\text { health literacy can determine the } \\
\text { low adherence to treatment, by } \\
\text { requiring more behavioral and } \\
\text { clinical educational interventions, } \\
\text { to achieve and maintain optimal } \\
\text { levels of adherence, virologic } \\
\text { suppression and long-term } \\
\text { treatment success. }\end{array}$ \\
\hline $\begin{array}{l}\text { Requesting help } \\
\text { to understand } \\
\text { medical } \\
\text { information } \\
\text { among people } \\
\text { living with HIV } \\
\text { and poor health } \\
\text { literacy }{ }^{(8)} \text {. }\end{array}$ & 2013 & $\begin{array}{l}\text { Analysis of adherence to } \\
\text { antiretroviral therapy for } \\
\text { people living with HIV who } \\
\text { had poor health literacy skills. } \\
\text { Sample: } 474 \text { participants. }\end{array}$ & $\begin{array}{l}\text { Five sources of data were collected } \\
\text { in the current study: literacy } \\
\text { assessments, information-related } \\
\text { assistance interviews, health } \\
\text { behavior assessments, unannounced } \\
\text { medication adherence pill counts, } \\
\text { and chart abstracted viral load and } \\
\text { CD4 counts. }\end{array}$ & $\begin{array}{l}\text { Individuals who sought } \\
\text { informational assistance were } \\
\text { significantly more likely to adhere } \\
\text { to multiple strategies. However, } \\
\text { despite asking for information and } \\
\text { using more strategies of control, } \\
\text { participants who requested } \\
\text { informational assistance showed } \\
\text { lower adherence to treatment and } \\
\text { less suppression of HIV replication. } \\
\text { People living with HIV with poor } \\
\text { skills and health literacy could } \\
\text { benefit from medication adherence } \\
\text { programs. }\end{array}$ \\
\hline $\begin{array}{l}\text { Program to } \\
\text { enhance health } \\
\text { literacy and } \\
\text { treatment } \\
\text { adherence in } \\
\text { low-income } \\
\text { HIV-infected } \\
\text { Latino men and } \\
\text { women. Aids } \\
\text { Patient Care and } \\
\text { STDS }^{(15)} \text {. }\end{array}$ & 2003 & $\begin{array}{l}\text { Evaluation of acceptance and } \\
\text { effectiveness of a program } \\
\text { to improve health literacy } \\
\text { in low-income Latino men } \\
\text { and women with HIV, } \\
\text { who received antiretroviral } \\
\text { therapy. It was a program of } \\
\text { instructional modular support } \\
\text { with follow-up of } 5 \text { weeks to } 6 \\
\text { months by a nurse. Objectives } \\
\text { of the program were to improve } \\
\text { knowledge and skills, build } \\
\text { confidence to follow the } \\
\text { treatment regimen, and teach } \\
\text { assertive communication. } \\
\text { Sample: } 81 \text { participants. }\end{array}$ & $\begin{array}{l}\text { Participants rated the program highly } \\
\text { on measures of satisfaction, providing } \\
\text { evidence of its acceptability. The } \\
\text { effectiveness of the program was } \\
\text { assessed in comparisons of the } \\
\text { intervention }(n=41) \text { and standard } \\
\text { care only }(n=40) \text { groups at baseline } \\
\text { and 6-week intervals. }\end{array}$ & $\begin{array}{l}\text { Program participants showed } \\
\text { significant improvement on } \\
\text { knowledge related to HIV/Aids, its } \\
\text { treatment, and understanding of } \\
\text { the technical terms related to HIV } \\
\text { infection, compared to participants } \\
\text { in the comparison group. }\end{array}$ \\
\hline
\end{tabular}

\section{DISCUSSION}

This study sought to identify research in the literature involving health literacy and HIV/Aids, trying to observe the relationship between literacy and following the guidelines of health, in addition to analyzing aspects that could be implemented to facilitate the health education of these patients. Analysis of the level of health literacy of individuals for which the activities of guidance and health education will be developed is extremely important so that the strategies used are effective. Studies show that low health literacy has negative consequences on the patient's understanding of health-related information ${ }^{(19-20)}$.

Regarding the levels of evidence ${ }^{(14)}$, it is noted that one of the articles was level $\mathrm{II}^{(15)}$, representing the results from a well-designed randomized controlled trial, while other articles were level $\mathrm{VI}$, in which the evidence is derived from descriptive or qualitative studies. This is justified by the fact that health literacy is a subjective aspect of the human being, which is more convenient to evaluate by such studies. However, there are few studies on health literacy in the context of people living with HIV/Aids, a fact evidenced by this research, 
in which 130 articles were found in six databases, and 14 were selected. In Brazil, this issue is little studied in people with HIV/Aids, which was also demonstrated in this study, as the selected studies were from the United States and the United Kingdom. This may occur due to the difficulty of assessing functional literacy in health in specific populations, as well as the lack of knowledge by health professionals on this aspect so important to the conduct of the treatment, because patients with high education often do not follow adequately the instructions of the health team.

Whereas HIV/Aids have developed most intensely in populations with predominantly low socioeconomic status, misinformation and poor schooling, it is essential to develop strategies that meet the needs of this clientele that is often devoid of financial, educational and even humanitarian resources, as well as the discrimination and stigma that still occur, arising from the initial epidemiology of HIV/Aids, which was dominated by groups considered at risk ${ }^{(6,26)}$.

The educational technologies used were intended to improve adherence for people living with HIV/Aids in terms of prevention, reinfection with the virus, or antiretroviral treatment. Technology is the result of processes implemented from everyday experience and research, for the development of a set of scientific knowledge, building material products or not, with the purpose of provoking interventions for a given practical situation ${ }^{(27)}$. The technologies developed by health professionals should aim to make it easier to educate and to improve the quality of care that is provided.

Health education, as process-oriented strategies to help the individual to adopt practices that enable a healthy state, continues to be reflected by politicians, institutions and health professionals, as well as other areas of knowledge. Faced with this, strategies used with the aid of educational technologies can be beneficial, especially considering low health literacy with HIV/Aids, which requires appropriate guidance for improved understanding. Many patients report not understanding health care-related information, and that the assessment of health literacy is important for understanding their real needs. Low health literacy has been associated with less knowledge about their own health status and the meaning of the CD4+ T cell count and viral load, which may develop misconceptions, or non-recognition of the goals of treatment ${ }^{(19-20)}$.

Studies evaluating the levels of health literacy concluded that about half of the eight years of schooling, which reduced their ability to know and understand health guidelines. In addition, new epidemiological evidence suggests that people who are more informed about people living with HIV/Aids had an educational level of less than HIV transmission are less vulnerable to contracting the virus, as well as that knowledge can make already infected individuals less likely to transmit the virus ${ }^{(20,22)}$. Studies that sought to examine the relationship between health literacy and adherence to antiretroviral therapy were identified. The shortage of food, hunger, depression, internalized stigma, drug use and other social stressors related to HIV contributed to non adherence to antiretroviral therapy ${ }^{(23)}$; furthermore, an association was proven between health literacy and adherence to antiretroviral $s^{(8,23,25)}$.
Antiretroviral drugs are the single most important advance in the treatment of HIV infection. However, studies showed that many patients did not adhere to medication appropriately, identifying the ineffective management of the therapeutic regimen. Thus, the concept of medication adherence means the use of drugs in at least $80 \%$ of its total, observing schedules, doses and length of treatment ${ }^{(6,23,25)}$. The combinations of antiretroviral drugs dramatically reduce viral load and improve health and quality of life of people living with HIV/Aids, as well as directly contribute to a significant reduction in mortality from Aids. To reduce viral replication, adherence of at least $80 \%$ becomes necessary ${ }^{(28)}$.

Although Brazil is an example for the world in terms of having a program that offers good response to the epidemic of HIV/ Aids, access to antiretroviral drugs is not universal. Despite being distributed free of charge, social and economic inequality causes problems regarding compliance with the treatment. Furthermore, the large number of tablets to be ingested per day, and adverse effects are factors responsible for the low medication adherence $^{(6)}$. Moreover, the specific sources of stress, which can be social or health-related, poverty itself and other stressors related to the poor, may prove to be important in addressing treatment noncompliance for HIV infection and Aids ${ }^{(23)}$.

Despite limited health literacy being a factor that may predict poor adherence to treatment, little is known about the strategies used to improve understanding of instructions and health information, which is a challenge. Patients should inform their health care providers about their reading difficulties. It is known that more than two thirds of patients with low health literacy admit to having reading difficulties, while $40 \%$ of those who admit this difficulty are ashamed to share the problem with family and friends ${ }^{(8)}$. Due to these findings, professionals should also have access to family or friends of patients during consultations, because they can provide information and help in the understanding of health information.

Considering economically disadvantaged populations living with HIV/Aids, it is emphasized that cognitive and behavioral approaches facilitate adherence to antiretroviral drugs and may have a long term beneficial effect ${ }^{(8,23-24,29-30)}$. Thus, it is clear that health education is extremely important in populations with HIV/Aids. However, care should be taken in order to overcome the obstacles that may result from inadequate communication. Therefore, understanding and analysis of health literacy is essential.

This study is particularly important for nursing professionals, who carry out health education activities on a daily basis for all patients, especially those with specific health needs, low education, low income and problems of functional literacy in health. Understanding the level of functional literacy in health of people living with HIV/Aids is necessary for a proper follow-up treatment. This research has shown, through the articles analyzed, that investigating functional literacy in population health is a primary step for the implementation of any educational strategy, but there is a lack of studies in the area, and longitudinal research using scales to assess health literacy more specifically is needed ${ }^{(7,19-22)}$. In addition, the use of educational technologies is a current trend that improves patients' knowledge about the 
conduct of the treatment, but should be used with caution, especially considering the patient access to different types of existing technologies ${ }^{(15-18)}$. It is also noteworthy that in areas of extreme poverty, a larger number of behavioral and clinical educational interventions is required to achieve and maintain optimal levels of adherence, and virologic suppression successful long-term treatment ${ }^{(15,23-25)}$.

\section{CONCLUSION}

This study examined the scientific knowledge about the research of functional health literacy of people living with HIV/ Aids. The content of the studies involved health literacy and educational technologies, adherence to antiretroviral therapy, as well as assessing the level of health literacy of people living with HIV/Aids. We emphasize that in general, the goal was to determine the conditions of health literacy of people living with HIV/Aids for the implementation of strategies that could improve adherence to health guidance.

However, health guidelines must be introduced after obtaining knowledge about the life conditions of patients, as often deprivation can ultimately undermine the achievement of health professionals' guidelines. Noteworthy is the low socioeconomic status of this population, because even if the patient was oriented and understood the importance of different measures for health, they may have been unable to put them into action, due to the fact they did not have the resources to maintain quality of life. In this context, it is important to search for a social support network, with emphasis on an intersectoral approach to health promotion that can be addressed for the benefit of the patient.

A limitation of this research was the small number of articles involving the theme HIV/Aids and functional literacy in health. This fact also interferes in the discussion of the study's findings, as well as demonstrates the need for more research in the area. This study showed the importance of health literacy for working with patients with HIV/Aids, especially considering individuals who do not possess the minimum necessary for survival, which makes it relevant and encourages further research on the topic. Strategies that promote healthy practices for people with poor education and socioeconomic level are highlighted within this context. Health professionals, especially nurses should pay attention to health education.

Finally, it emphasized the role of health professionals in maintaining the quality of life of people living with HIV/Aids, who can carry out health education activities. It is also important to remember that the activities related to health education require scientific knowledge and personalized interventions, and that they should also involve the patient's family, because the guidelines apply to every situation or context.

\section{REFERENCES}

1. Alimohamadi $\mathrm{Y}$, Tabatabaee $\mathrm{H}$, AfsarKazerooni $\mathrm{P}$, Vahedi $\mathrm{S}$, Enaami M, Teimourizad A. Epidemiologic characteristics of HIV-positive patients referring to behavioral diseases consultation center in Shiraz, Iran. Med J Islam Repub Iran [Internet]. 2014[cited 2014 Oct 20];28:147. Available from: http://mjiri.iums.ac.ir/browse.php?a_id $=25$ 90\&slc_lang $=\mathrm{en} \& \mathrm{sid}=1 \& \mathrm{ftxt}=1$

2. Castel AD, Magnus M, Greenberg AE. Update on the Epidemiology and Prevention of HIV/AIDS in the USA. Curr Epidemiol Rep [Internet]. 2015[cited 2014 Nov 10];2(2):110-9. Available from: http://link.springer.com/ar ticle/10.1007\%2Fs40471-015-0042-8

3. Ahmetagicn S, Porobić-Jahic H, Piljic D, Custovic A, Sabitovic D, Zepic D. Clinical and epidemiological characteristics of HIV infection/AIDS in hospitalized patients. Mater Sociomed [Internet]. 2015[cited 2015 Jun 10];27(1):27-30. Available from: http://www.scopemed. org/?mno $=180759$

4. Mombelli MA, Barreto MS, Arruda GO, Marcon SS. AIDS epidemic in the triple frontier: subsidies for professional practice. Rev Bras Enferm [Internet]. 2015[cited 2015 Jun 10];68(3):429-37. Available from: http://www.scielo.br/ pdf/reben/v68n3/en_0034-7167-reben-68-03-0429.pdf

5. Williams AB, Wang H, Burgess J, Li X, Danvers K. Cultural adaptation of an evidence-based nursing intervention to improve medication adherence among people living with HIV/AIDS (PLWHA) in China. Int J Nurs Stud [Internet]. 2013[cited 2014 Dec 19];50(4):487-94. Available from:
http://www.journalofnursingstudies.com/article/S0020 -7489(12)00291-X/abstract

6. Cunha GH, Galvão MTG. Nursing diagnoses in patients with human immunodeficiency vírus/acquired immunodeficiency syndrome in outpatient care. Acta Paul Enferm [Internet]. 2010[cited 2014 Dec 22];23(4):526-32. Available from: http://www.scielo.br/pdf/ape/v23n4/en_13.pdf

7. Nokes KM, Coleman CL, Cashen M, Dole P, Sefcik E, Hamilton MJ, et al. Health literacy and health outcomes in HIV seropositive persons. Res Nurs Health [Internet]. 2007[cited 2014 Dec 12];30(6):620-7. Available from: http://onlineli brary.wiley.com/doi/10.1002/nur.20219/pdf

8. Kalichman SC, Pellowski J, ChenY. Requesting help to understand medical information among people living with HIV and poor health literacy. Aids Patient Care STDS [Internet]. 2013 [cited 2014 Dec 8];27(6):326-32. Available from: http://online.liebertpub.com/doi/pdf/10.1089/ apc.2013.0056

9. Passamai MPB, Sampaio HAC, Dias AMI, Cabral LA. Functional health literacy: reflections and concepts on its impact on the interaction among users, professionals and the health system. Interface [Internet]. 2012[cited 2014 Oct 11];16(41):301-4. Available from: http://www.scielo. br/pdf/icse/v16n41/en_aop2812.pdf

10. Välimäki M, Makkonen P, Mockiene V, Aro I, Blek-Vehkaluoto $M$, Istomina $N$, et al. Nursing and midwife students' willingness to provide care to patients with HIV/AIDS - a comparative study in Finland, Estonia and Lithuania. Nurse 
Educ Today [Internet]. 2010[cited 2014 Oct 27];30(7):6749. Available from: http://www.nurseeducationtoday.com/ article/S0260-6917(10)00016-X/pdf

11. Johnson A. Health literacy, does it make a difference? Aust J Adv Nurs [Internet]. 2014[cited 2015 Jan 5];31(3):39-45. Available from: http://www.ajan.com.au/Vol31/Issue3/5Joh nson.pdf

12. Mendes KDS, Silveira RCCP, Galvão CM. [Integrative literature review: a research method to incorporate evidence in health care and nursing]. Texto Contexto Enferm [Internet]. 2008[cited 2014 Jan 16];17(4):758-64. Available from: http:// www.scielo.br/pdf/tce/v17n4/18.pdf Portuguese.

13. Souza MT, Silva MD, Carvalho R. Integrative review: what is it? How to do it? Einstein [Internet]. 2010[cited 2014 Jan 20];8(1):102-6. Available from: http://www.scielo.br/pdf/ eins/v8n1/1679-4508-eins-8-1-0102.pdf

14. Melnyk BM, Fineout-Overholt E. Making the case for evidence-based practice. In: Melnyk BM, Fineout-Overholt E, editors. Evidence-based practice in nursing \& healthcare: a guide to best practice. Philadelphia: Lippincott Williams \& Wilkins; 2011.

15. Servellen GV, Carpio F, Lopez M, Garcia-Teague L, Herrera G, Monterrosa F, et al. Program to enhance health literacy and treatment adherence in low-income HIV-infected latino men and women. AIDS Patient Care STDS [Internet]. 2003[cited 2014 Jan 25];17(11):581-94. Available from: http://online. liebertpub.com/doi/pdf/10.1089/108729103322555971

16. Rikard RV, Thompson MS, Head R, Mcneil C, White C. Problem posing and cultural tailoring: developing an HIV/AIDS health literacy toolkit with the African American community. Health Promot Pract [Internet]. 2012[cited 2014 Jan 11];13(5):626-36. Available from: http://hpp. sagepub.com/content/13/5/626.full.pdf + html

17. Moore JO, Boyer EW, Safren S, Robbins GK, Boudreaux ED, Rosen $\mathrm{R}$, et al. Designing interventions to overcome poor numeracy and improve medication adherence in chronic illness, including HIV/AIDS. J Med Toxicol [Internet]. 2011[cited 2014 Jan 17];7(2):133-8. Available from: http://link.springer. com/article/10.1007\%2Fs13181-011-0149-3

18. Kalichman SC, Cherry J, Cain D. Nurse-delivered antiretroviral treatment adherence intervention for people with low literacy skills and living with HIV/AIDS. J Assoc Nurses AIDS Care [Internet]. 2005[cited 2014 Jan 9];16(5):315. Available from: http://www.nursesinaidscarejournal. org/article/S1055-3290(05)00227-X/pdf

19. Zukoski AP, Thorburn S, Stroud J. Seeking information about HIV/AIDS: a qualitative study of health literacy among people living with HIV/AIDS in a low prevalence context. AIDS Care [Internet]. 2011[cited 2014 Jan 22];23(11):1505-8. Available from: http://www.tandfonline.com/doi/pdf/10.1080/095401 21.2011 .582077

20. Mooss A, Brock-Getz P, Ladner R, Fiaño T. The relationship between health literacy, knowledge of health status, and beliefs about HIV/AIDS transmission among Ryan White clients in Miami. Health Educ J [Internet]. 2012[cited 2014 Jan 30];72(3):292-9. Available from: http://hej. sagepub.com/content/72/3/292.full.pdf + html
21. Ciampa PJ, Vaz LM, Blevins M, Sidat M, Rothman RL, Vermund $\mathrm{SH}$, et al. The association among literacy, numeracy, HIV knowledge and health-seeking behavior: a populationbased survey of women in rural Mozambique. PLoS One [Internet]. 2012[cited 2014 Jan 31];7(6):e39391. Available from: http://journals.plos.org/plosone/article/asset?id = 10.13 71\%2Fjournal.pone.0039391.PDF

22. Ohl M, Harris A, Nurudtinova D, Cai X, Drohobyczer D, Overton ET. Do brief screening questions or provider perception accurately identify persons with low health literacy in the HIV primary care setting? AIDS Patient Care STDS [Internet]. 2010[cited 2014 Feb 12];24(10):623-9. Available from: http:// online.liebertpub.com/doi/pdf/10.1089/apc.2009.0319

23. Kalichman SC, Grebler T. Stress and poverty predictors of treatment adherence among people with low-literacy living with HIV/AIDS. Psychosom Med [Internet]. 2010[cited 2014 Feb 9];72(8):810-6. Available from: http://www.ncbi.nlm.nih. gov/pmc/articles/PMC3016469/pdf/nihms260158.pdf

24. Kalichman SC, Pope H, White D, Cherry C, Amaral CM, Swetzes C, et al. Association between health literacy and HIV treatment adherence: further evidence from objectively measured medication adherence. J Int Assoc Physicians AIDS Care [Internet]. 2008[cited 2014 Feb 3];7(6):317-23. Available from: http://jia.sagepub.com/content/7/6/317.full. $\mathrm{pdf}+\mathrm{html}$

25. Nachega JB, Morroni C, Zuniga JM, Schechter M, Rockstroh J, Solomon S, et al. HIV treatment adherence, patient health literacy, and health care provider-patient communication: results from the 2010 AIDS treatment for life international survey. J Int Assoc Physicians AIDS Care [Internet]. 2012[cited 2014 Jan 22];11(2):128-33. Available from: http://jia.sagep ub.com/content/11/2/128.full.pdf + html

26. Galvão MTG, Cunha GH, Machado MMT. Dilemmas and conflicts of being a mother with HIV/AIDS. Rev Bras Enferm [Internet]. 2010[cited 2014 Jan 29];63(3):371-6. Available from: http://www.scielo.br/pdf/reben/v63n3/a04v63n3.pdf

27. Rocha PK, Prado ML, Wal ML, Carraro TE. Care and technology: approaches through the Care Mode. Rev Bras Enferm [Internet]. 2008[cited 2014 Jan 20];61(1):113-6. Available from: http://www.scielo.br/pdf/reben/v61n1/18.pdf

28. Volandes $\mathrm{AE}$, Paasche-Orlow M, Gillick MR, Cook EF, Shaykevich S, Abbo ED, et al. Health literacy not race predicts end-of-life care preferences. J Palliat Med [Internet]. 2008[cited 2014 Jan 17];11(5):754-62. Available from: http:// online.liebertpub.com/doi/pdf/10.1089/jpm.2007.0224

29. Servellen GV, Brown JS, Lombardi E, Herrera G. Health literacy in low-income latino men and women receiving antiretroviral therapy in community-based treatment centers. AIDS Patient Care STDS [Internet]. 2003[cited 2014 Jan 10];17(6):283-98. Available from: http://online. liebertpub.com/doi/pdf/10.1089/108729103322108166

30. Nokes $\mathrm{K}$, Johnson MO, Webel A, Rose CD, Phillips JC, Sullivan $\mathrm{K}$, et al. Focus on increasing treatment self-efficacy to improve human immunodeficiency virus treatment adherence. J Nurs Scholarsh [Internet]. 2012[cited 2014 Feb 19];44(4):403-10. Available from: http://onlinelibrary. wiley.com/doi/10.1111/j.1547-5069.2012.01476.x/pdf 